\title{
An Economic Assessment of the Impact on Agriculture of the Proposed Changes in EU Biofuel Policy Mechanisms
}

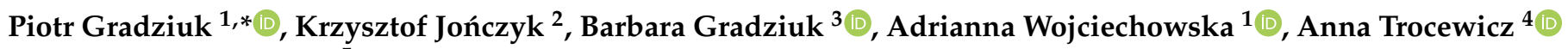 \\ and Marcin Wysokiński ${ }^{5}$ \\ 1 Economic Modelling Department, Institute of Rural and Agricultural Development, \\ Polish Academy of Sciences, Nowy Świat 72, 00-330 Warsaw, Poland; awojciechowska@irwirpan.waw.pl \\ 2 Institute of Soil Science and Plant Cultivation-State Research Institute, Czartoryskich 8, \\ 24-100 Puławy, Poland; kjonczyk@iung.pulawy.pl \\ 3 Department of Management and Marketing, Faculty of Agrobioengineering, University of Life Sciences in \\ Lublin, Akademicka 13, 20-950 Lublin, Poland; barbara.gradziuk@up.lublin.pl \\ 4 Department of Economics, Faculty of Economic Sciences, Pope John Paul II State School of Higher Education, \\ Sidorska 95/97, 21-500 Biała Podlaska, Poland; usanna@op.pl \\ 5 Institute of Economics and Finance, Warsaw University of Life Sciences-SGGW, 02-787 Warsaw, Poland; \\ marcin_wysokinski@sggw.edu.pl \\ * Correspondence: pgradziuk@irwirpan.waw.pl
}

Citation: Gradziuk, P.; Jończyk, K.; Gradziuk, B.; Wojciechowska, A.; Trocewicz, A.; Wysokiński, M. An Economic Assessment of the Impact on Agriculture of the Proposed Changes in EU Biofuel Policy Mechanisms. Energies 2021, 14, 6982. https://doi.org/10.3390/en14216982

Academic Editor: David Borge-Diez

Received: 22 September 2021

Accepted: 19 October 2021

Published: 25 October 2021

Publisher's Note: MDPI stays neutral with regard to jurisdictional claims in published maps and institutional affiliations.

Copyright: (C) 2021 by the authors. Licensee MDPI, Basel, Switzerland. This article is an open access article distributed under the terms and conditions of the Creative Commons Attribution (CC BY) license (https:// creativecommons.org/licenses/by/ $4.0 /)$.

\begin{abstract}
In Poland, rapeseed production has been the fastest growing branch of plant production since 2000. Rapeseed yields have increased 2.5 times in the last 20 years. The main reason for this trend was the implementation of obligations resulting from legal acts by Member States relating to increasing the share of RES in the structure of primary energy production, and in particular relating to the share of biofuels in fuels used in transport. In Poland in the years 2010-2020, about 1.0-1.6 million tonnes of rape seeds were used for this purpose annually. Due to the fact that biofuel production competes for raw materials with the food economy, at the end of the first decade of the 21st century, many representatives of various circles intensified their voices, calling for withdrawal from the policy supporting the biofuel sector, which may have resulted in a decrease in oilseed plant cultivation areas. As a result of the research conducted here, it was determined that the place of oilseed rape in the sowing structure will be taken by rye, triticale and, on good soils, by wheat. Compared to rape, their production is characterised by lower income per 1 ha; in the years 2013-2019, these differences amounted to: wheat-8 EUR, triticale-102.3 EUR, and rye-168 EUR. This situation will deteriorate the value cereal cultivation sites and will result in a decrease in their yields. On the basis of the conducted research, the estimated value of rape as a forecrop for wheat, triticale, and rye was, respectively: 103.7; 64.6 and 46.7 EUR. An additional advantage of oilseed rape is that it is an excellent bee resource and is classified as a commodity crop, i.e., one from which significant amounts of honey can be obtained, with a net value of EUR 55 per hectare. In addition, in many agricultural holdings, as a result of forecasted changes in plant production, there will be an accumulation of field work during the harvest period, which will also affect the worse use of machinery and storage areas. The consequence of increasing the area under which cereal crops and their supply can grow may be the decline in production profitability and thus the income situation of farms, but this will be assessed at the next stage of research.
\end{abstract}

Keywords: renewable energy; biofuels; biodiesel; legal sources on renewable energy; oilseeds and rape; profitability of production; crop rotation; beekeeping

\section{Introduction}

The first attempts to utilise biofuels to power engines were made by the end of the 19th century [1-3]. The self-ignition engine constructed in 1893 by Rudolf Diesel could be fuelled with both petroleum-derivative fuels and oils of both vegetable and animal origin [4-6]. 
Similarly, ethanol has a long history as an engine fuel [1,2,7-9]. It had already been used at the end of the 19th century in engines designed by Samuel Morey, Nicholas Otto, and Henry Ford. In the 1920s in the USA, about the fuel sold 20\% accounted for ethanol $[10,11]$. Due to much higher production costs in relation to fuels produced from crude oil, their importance was marginalized [5,12-14]. In the 20th century, a downward price trend prevailed, with periods of growth occurring sporadically and most often as a result of political or economic crises, especially after 1974 (OPEC embargo, Iranian revolution, Gulf War). After their subsidence, prices declined, and some economic crises, such as the recession of the early 1980s, the Asian crisis (1997), the financial market crisis (2008) and the coronavirus pandemic crisis (2020), caused significant price decreases. The concept of Rudolf Diesel or Henry Ford, based on the use of vegetable oils to run engines and produce other biofuels, was reintroduced in the 1980s. This was mainly due to four reasons:

The first of them can be expressed in the shortest terms by quoting Alvin Toffler [15]: "The condition for the existence of any civilisation—old or new-is energy". According to the International Energy Outlook 2002 report prepared by the Energy Information Administration (EIA), which is a part of the US Department of Energy, between 2000 and 2020, a significant increase in energy consumption in the world was projected, which was to reach $60 \%$ and increase from 382 to 612 quadrillion Btu [16]. These predictions turned out to be accurate because by 2018 , the world's energy consumption increased by $48.2 \%$ compared to 2000. However, in a report published in 2020 by the International Energy Agency (IEA), it was assumed that by the middle of this century, energy consumption would increase by nearly 50\% compared to 2018 [17]. Thus, energy was, is, and will be the main determinant of economic activity and the development of civilization because every management process must be powered by energy [18-21].

The second consideration is that resources are limited, which may reduce business efficiency or even hinder economic development. The energy barrier to economic development as a result of dwindling coal reserves and rising mining costs was already presented by William Stanley Jevons [22] in the mid-19th century, who stated that technological progress and other energy sources would not change this situation. This view was rejected by neoclassical economists, who did not acknowledge the possibility of limiting growth in the long term. Indeed, they considered that under optimal market conditions, there is a harmonised adjustment of individual resources, ensuring balance while fully exploiting production potential [23-25]. The basis of such a judgment is the assumption that prices increase with the depletion of resources. This triggers incentives to increase the supply of these resources or their substitutes or to introduce more efficient use methods, which reduces demand for them [26,27]. An example of this is the market for energy resources. In all of the scenarios considered, the share of conventional fuels-oil, gas and coal-is projected to decrease more rapidly after 2020, which is in line with the depletion of their resources and the associated increase in energy prices. Conventional resources will be replaced by renewable energy sources (RES) [17,28-31].

Another aspect is concern for the environment, as the intensive use and processing of traditional energy resources has a negative impact on natural resources. Since the last three decades of the 20th century, the most serious threat is related to climate change caused by the anthropogenic heating of the atmosphere as a result of increasing concentrations of greenhouse gases (GHG), especially $\mathrm{CO}_{2}$ [32]. There is a well-founded concern that this phenomenon may pose a threat to life for most of humanity and even to the whole of civilisation [33]. Hence, many circles and international organisations have made initiatives to take action to reduce GHG emissions. The first World Climate Conference held in 1979 established the World Climate Research Programme (WCRP), and its management was entrusted to the World Meteorological Organisation (WMO), the United Nations Environment Programme (UNEP), and the International Council for Scientific Union (ICSU). These organisations established the Intergovernmental Panel on Climate Change (IPCC) in 1988. The first significant effect of the IPCC activities was the preparation of the United Nations Framework Convention on Climate Change (UNFCCC), which was 
presented in 1992 at the United Nations Conference on Environment and Development (UNCED) in Rio de Janeiro. The main body of the convention became the Conference of the Parties (COP), which, since its first meeting in Berlin in 1995 (COP 1), regularly assesses the scale and course of climate change and its effects and develops strategies to respond to these changes [34]. The first significant effect of these activities was the signing of the Kyoto Protocol during COP 3, in which the 38 most industrialised countries and the European Union committed to reduce GHG, which was expressed in carbon dioxide equivalent, by at least 5\% below 1990 levels between 2008 and 2012 [35]. Due to protracted negotiations on a new global "climate agreement", COP 18 extended its validity until 31 December 2020 [36]. Although the Kyoto Protocol was a first significant step towards reducing greenhouse gas emissions, it did not solve the problem of global warming. This did not occur until climate policy re-prioritisation (among other things, under the influence of the financial crisis), which began to be seen as a factor for economic growth through "the development of clean or low-carbon technologies, the creation of new markets, industries and jobs" [37]. The latter led to the acceleration of negotiations and agreement on the content of a global climate agreement at COP 21 in Paris in December 2015 (the Paris Agreement) [38]. The European Union (EU) plays a very important role in reducing greenhouse gas emissions. The actions taken by the EU go far beyond the obligations arising from global climate agreements [39]. The European Green Deal has set out a clear vision of how to achieve climate neutrality by 2050 [40].

The fourth reason is the stagnation in demand for agricultural raw materials and food products, which is becoming a barrier to agricultural development. In countries with a developed economy, surpluses of agricultural raw materials have started to occur, which has led to a deterioration in the profitability of production and reduced incomes for farming families. One way of managing these surpluses is to use them for non-food purposes. The idea of "Chemurgy" was already promoted in the 1920s as a strategy for industries and governments who were interested in reviving the agricultural economy [41]. The USA reverted to this concept in the early 1980s. As part of the Growing Industrial Materiale programme, more than two thousand plant species have been tested for the raw material content sought by industries, of which several dozen have been selected and recommended for cultivation [42]. In Europe, the intensification of research into the cultivation of plants for industrial purposes dates back to 1982, when the European Commission recommended cooperation between agriculture and industry. This research resulted in a very long list of arable crops that can be used in several industries and branches of industry [43-45]. However, the direction of bioenergy has become dominant, which is mainly due to the growing interest in obtaining inexhaustible and ecologically clean energy sources [46-48]. The records in the White Paper "Energy for the Future: renewable sources of energy" prepared by the European Commission in 1997 showed that by 2010, the production of firstgeneration biofuels, mainly comprising biodiesel produced from rapeseed, will increase the most [49].

As a result of these factors, between 1997 and 2017, biodiesel production in the EU 28 increased from 332.9 ktoe to $12,239.4$ ktoe. First-generation biofuels are very controversial. Their use is questioned for ethical [50-53], economic [54-56], and environmental [57,58] reasons. The production of biofuels has thus become the subject of numerous discussions, polemics, comments, and contradictory judgments: from extreme disapproval and objections $[59,60]$ to equally extreme affirmation and approval [61,62]. Hence, the frequent changes in legal regulations governing this market [63-66].

The interest of scientific environment concerning the issue of biofuels was mainly stimulated by the discussion in the context of climate change, energy and food security, and the legitimacy of support for the development of their use on both national and EU (European Union) levels. On the other hand, there is a lack of comprehensive assessments relating to the agricultural sector on a micro-scale, which is the key supplier of raw materials for their production. This primarily results from the problem of identification, and especially quantification, of a wide range of effects that are the result of changes in the 
structure of plant production. The main motivation of our study has been to assess the impact of the EU biofuel policy on the agricultural sector. In this paper, we illustrate this for biodiesel in Poland, which is the largest producer of biodiesel produced from domestic feedstock in the EU.

\section{Background}

\subsection{What Are Biofuels?}

In the RES literature, the term "biofuel" is defined very differently. It is most often used to refer to fuels produced from biomass, which can take solid, liquid, or gaseous forms $[2,67,68]$. However, since it started to be widely used as motor fuel, the term is dedicated to any type of liquid or gas produced from biomass that can be used as a substitute for fossil fuels [69,70]. According to the International Energy Agency [71], biofuels are "liquid and gaseous fuels produced from biomass-organic matter derived from plants or animals". Biofuels are usually classified according to two categories: type of biomass and production technologies.

Biomass sources are defined in Directive 2018/2001 of the European Parliament and of the European Council (EU) as "the biodegradable fraction of products, waste and residues from biological origin from agriculture, including vegetal and animal substances, from forestry and related industries, including fisheries and aquaculture, as well as the biodegradable fraction of waste, including industrial and municipal waste of biological origin". Biomass fuels refer to gaseous and solid fuels produced from biomass and, biofuels refer to liquid fuel for transport produced that is from biomass [66].

Due to the diverse composition and suitability for the various conversion methods that are used, the following biomass categories can be distinguished [72-74]:

- Raw materials containing significant amounts of sugar and starch (sugar beet, cereals, potatoes);

- $\quad$ Lignocellulosic biomass (wood and its waste, targeted wood crops, straw);

- Oilseeds and animal fats;

- $\quad$ Organic waste (organic fertilisers and food and municipal waste);

- Algal biomass.

Depending on the type of biomass that is used, the following biofuel generations can be distinguished [75]:

- $\quad$ First generation (edible feedstocks);

- $\quad$ Second generation (non-edible biomass sources);

- Third generation (microalgae biomass);

- $\quad$ Fourth generation (genetic modification of the microalgae).

In 2017, the main raw materials that were used in the production of bioethanol were sugar cane, maize grain (Brazil, USA), biodiesel soybean and palm oils, animal fats, used cooking oils, and rapeseed, which was mainly used in the EU [47,74]. Biofuels are commonly referred to as first-generation fuels, which is mainly due to the fact that they use conventional technologies during their production: alcoholic fermentation, mechanical pressing, and transesterification (hydrogenation) of oils and anaerobic digestion of organic biodegradable wastes to produce biogas [71]. Due to the controversy arising from the significant quantities of agricultural raw materials used to produce biofuels [50-60], research on the production of second, third, and fourth generation biofuels, known as advanced biofuels, has intensified since the beginning of the 21st century. The main substrates for their production are waste and residues of biological origin from agriculture, forestry and related industries, fisheries, aquaculture, and municipal and industrial waste of biological origin. The prospective development of next-generation biofuel production is [76]:

- Microbial conversion of lignocellulosic biomass (e.g., stalks, corn stover) into bioethanol or biobutanol;

- Transesterification of sustainably sourced FAME (i.e., biodiesel);

- Hydrotreatment of sustainably sourced vegetable oils or animal fats followed by alkane isomerisation and cracking to produce drop-in fuels (HVO/HEFA); 
- Thermochemical pathways starting with pyrolysis to produce biocrude or gasification of biomass for syngas.

Based on experience to date, it can be concluded that apart from HVO technology, the production of other advanced biofuels is still under intensive development and work on optimising production efficiency, minimising production costs, and seeking non-commercial sources of financing is being undetaken [76-78].

\subsection{Legal Conditions}

The growing interest in opportunities to increase energy production from renewable sources in the EU began after the first oil crisis. However, the energy obtained in this way was more expensive than conventional energy in most applications. Therefore, the EU and individual countries have taken political, legal, administrative, and financial measures to achieve this objective as efficiently as possible. The first regulations concerning the support for renewable energy sources were included in Council Regulation (EEC) No 1302/78 of 12 June 1978, which discussed the granting of financial support for projects to exploit alternative energy sources [79]. In contrast, the Council resolution of 9 June 1980 concerning Community energy policy objectives for 1990 and the convergence of the policies of the Member States required the Commission to integrate RES into the framework of community energy policies [80]. Further actions include an assessment of the potential, the state of the technology, economic conditions, and barriers related to increasing the use of RES [81,82]. Research and development work has also been intensified, among other initiatives, within the framework of the programmes Valoren, Altener, Coopener, Intelligent Energy-Europe Programme, Joule-thermie, Save, Steer, and Synergy of subsequent European Framework Programme for Research and Innovation.

A milestone on the way to increase the importance of RES in the EU was the publication of The Green Paper [83] and White Paper [49] between 1996 and 1997, which were entitled "Energy for the future: renewable sources of energy". At that time, these were key documents that were political and strategic in character, setting directions for long-term policy, with quantitative targets in the form of doubling the share of RES in the structure of primary energy production from 6 to 12\% between 1998 and 2010. They indicated that biomass would be the most important among renewable energy sources. Its share in the production of liquid fuels was predicted to increase (40-60 times) compared to electricity (ten times) and thermal energy (two times). These documents also formulate the need to introduce appropriate legal regulations and to secure sources of funding to achieve these ambitious goals [84].

In 2000, the Commission proposed the first two EU directives for RES, the promotion of renewable electricity and the development of biofuels in transport. The first was adopted in 2001 (2001/77/EC), and the second objective pertaining to the development of biofuels was adopted in 2003 (2003/30/EC). The biofuels directive obliged Member States to set national indicative targets to set reference values of $2 \%$ share for biofuel consumption in transport by 31 December 2005 and obliged them to increase those shares to 5.75\% in 31 December 2010 [85]. To meet these requirements Member States used two main tools: tax exemptions and biofuels obligations. Additionally, they introduced a special "energy crop payment" of EUR 45 per hectare (a maximum guaranteed area of 1.5 million hectares). These measures were complemented by the extension of offers for preferential loans, guaranteed lending, and loans to small businesses for renewable energy investments by financial institutions such as the European Investment Bank (EIB) and the European Bank for Reconstruction and Development (EBRD). Despite the instruments used, the market share of biofuels in 2005 was only $1.4 \%$ [86].

Although in those first years, there were problems with the implementation of Directive 2003/30/EC in some countries, as there were intense discussions in the EU regarding increasing the market share of biofuels $[87,88]$. In 2009, the European Parliament and the Council adopted a climate policy package in which the European Union committed to reducing greenhouse gas emissions expressed as a $\mathrm{CO}_{2}$ equivalent by $20 \%$ by 2020 (if 
other developed countries made similar commitments, then the reduction could be as high as $30 \%$ ). In the same period, the EU should have also increased the share of renewable energy in terms of total energy production from 8.5 to $20 \%$ to $10 \%$-the share of biofuel in transport fuel—and reduce energy consumption by $20 \%$. The biofuel sector was mainly covered by two directives:

- Directive 2009/28/EC (RED) of the European Parliament and by the Council meeting of 23 April 2009 on the promotion of the use of energy from renewable sources and the amendment and subsequent appeal of Directives 2001/77/EC and 2003/30/EC (Text with EEA relevance) [89];

- Directive 2009/30/EC of the European Parliament and by the Council meeting of 23 April 2009 that amended Directive 98/70/EC regarding the specification of petrol, diesel, and gas-oil and introduced a mechanism to monitor and reduce greenhouse gas emissions and amended Council Directive 1999/32/EC regarding the specification of fuel used by inland waterway vessels and repealed Directive 93/12/EEC (Text with EEA relevance) [90].

The results of the researched obtained within the European Framework ProgrammeHorizon 2020 have shown low efficiency in reducing $\mathrm{CO}_{2}$ emissions through the use of traditional biofuels, the so-called first generation, hence the proposals to reform the biofuel directives [91]. As a result of the discussions and analyses that have been conducted, the current solutions were modified and were included in Directive 2015/1513 of the European Parliament and during the Council meeting on 9 September 2015 [92]. One of the most important changes introduced by this Directive was to set a limit for the level of firstgeneration biofuels, with the Directive stating that their maximum quantity in 2020 could not exceed $7 \%$. Moreover, the condition for including such biofuels as renewable energy was to prove that the raw materials obtained for their production did not come from areas with high biodiversity value and high carbon intensity, and that their production complied with environmental requirements, which are regulated by the Code of Good Agricultural Practice in Poland [92]. The remaining part (at least 3\%) was to be produced from algae, by-products (e.g., straw, manure, seed hulls, etc.), or waste. A detailed list is provided in Annex IX of Directive 2015/1513 [65].

The necessity of meeting the EU's obligations arising from the Paris Agreement was the main determinant of the adoption of a new directive on the promotion of the use of energy from renewable sources (EU) 2018/2001 (RED II). In this document, the Member States agreed that the share of energy from renewable sources in gross final energy consumption in 2030 will be at least $32 \%$. After 2023, a proposal to increase this target will be considered if its production costs are significantly reduced or due to the EU's international commitments. This Directive also contains many significant changes relating to the issue of biofuels [66]. The most important are:

- A $14 \%$ share of renewable energy in final energy consumption in the transport sector by 2030 at least;

- $\quad$ Renewable energy used in the transport sector should also comprise renewable liquid and gaseous transport fuels of non-biological origin (e.g., hydrogen) and recycled carbon fuels (e.g., derived from plastic waste, rubber);

- First-generation biofuels should be divided into two categories: low (certification required) and high-risk Indirect Land Use Change -ILUC (cannot be higher than 2019 consumption levels-reduction from 31 December 2023 to $0 \%$ by 31 December 2030);

- Input of advanced biofuels and biogas produced from raw materials listed in Annex IX:

- $\quad$ Part A-min $0.2 \%$ in 2022, $\min 1 \%$ in 2025 and $\min 3.5 \%$ in 2030;

- Part B-maximum 1.7\%.

- New methodology for calculating GHG emissions. 


\subsection{Development of Biofuel Production in the UE}

Between 1996 and 1997, when the Green Paper [83] and White Paper [49] "Energy for the future: renewable sources of energy" were presented, the assumptions they made regarding the development of biofuel production in the European Union were considered unrealistic by most experts dealing with the issue [84]. However, the systematic implementation of the provisions contained in both documents and Directive 2003/30/EC contributed to the development of this economic sector. Between 1996 and 2010, the production of biodiesel in the EU increased by more than thirty times, and the production of bioethanol increased by nearly fifty times. This growth dynamic, which was mainly due to the continuation of the current EU policy on RES (Directives 2009/28/EC and 2015/1513/EC), continued. In 2018, bioethanol and biodiesel production increased by 60 and 50 times in relation to their production in 1996, respectively. In the considered period (1996-2018), the share of biofuels in the RES production structure also increased significantly, from $0.36 \%$ to $7.06 \%$ (Figure 1 ).

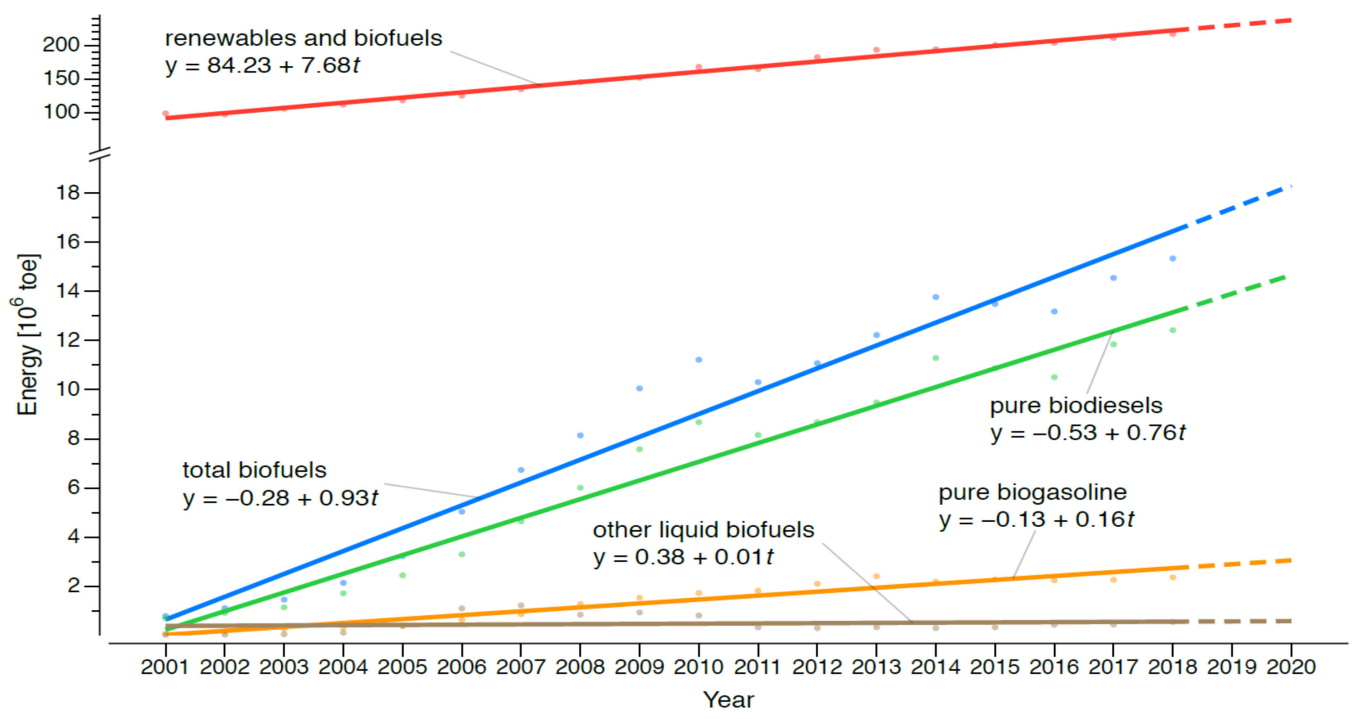

Figure 1. Share of biofuels in the energy production structure from renewable sources in the EU between 1996 and 2018.

In the EU, the predominant role among biofuels is played by biodiesel, the use of which increased from $85.8 \%$ in 1996 to $81.0 \%$ in 2018 . On an energy basis, biodiesel represents about 75 percent of the total transport biofuel market [93]. Globally, the share of biodiesel in the production of biofuels in 2018 was only $28.1 \%$, with bioethanol accounting for over 70\% [94]. The term biodiesel (pure) includes traditional biodiesel fatty acid methyl ester (FAME) and hydrotreated vegetable oil (HVO). The main factors that determined greater interest in the production of biodiesel in the EU rather than bioethanol were:

- The Blair House Agreement (provisions on the production of oilseeds under the Common Agricultural Policy) [93,95];

- Higher margin income in the production of oilseeds, which are the primary feedstock in the production of biodiesel, than cereals [96,97];

- The possibility of using by-products for feed purposes and thus reducing protein feed imports [93,96];

- Ensuring that oilseeds had a higher pre-crop value than cereals [96,98-103];

- Beekeeping profits [96,104-106];

- Protection of the natural environment through the reduction of NOx emissions and a closed $\mathrm{CO}_{2}$ cycle $[47,61,98,107]$;

- Increasing the number of jobs mainly in rural areas $[61,62,70,96,98,108]$;

- Improvements in energy security $[55,70,98,107]$.

The largest biodiesel producers in the EU are Germany, France, the Netherlands, Spain, Poland, and Italy (Table 1). 
Table 1. Biodiesel production and oilseed areas in selected EU countries.

\begin{tabular}{|c|c|c|c|c|c|c|c|c|c|c|c|c|c|c|c|c|c|c|c|c|c|}
\hline \multirow{3}{*}{ Specification } & \multirow{2}{*}{\multicolumn{7}{|c|}{ Pure Biodiesels (Ktoe) }} & \multicolumn{14}{|c|}{ Oilseed Areas (Kha) } \\
\hline & & & & & & & & \multicolumn{7}{|c|}{ Total } & \multicolumn{7}{|c|}{ Including Rape and Turnip Rape } \\
\hline & 1993 & 2000 & 2005 & 2010 & 2015 & 2018 & 2019 & 1993 & 2000 & 2005 & 2010 & 2015 & 2018 & 2020 & 1993 & 2000 & 2005 & 2010 & 2015 & 2018 & 2020 \\
\hline Germany & 0 & 222 & 1323 & 2736 & 2765 & 2960 & 3176 & 1088 & 1104 & 1371 & 1486 & 1304 & 1272 & 1018 & 1007 & 1078 & 1344 & 1461 & 1286 & 1228 & 957 \\
\hline France & 0 & 265 & 542 & 1788 & 2170 & 2435 & 1868 & 1443 & 1993 & 1935 & 2207 & 2239 & 2323 & 2082 & 559 & 1186 & 1232 & 1465 & 1499 & 1617 & 1122 \\
\hline Netherlands & 0 & 0 & 0 & 338 & 1440 & 1625 & 1739 & 2 & 1 & 2 & 3 & 2 & 3 & 2 & 2 & 1 & 2 & 3 & 2 & 2 & 1 \\
\hline Spain & 0 & 0 & 147 & 764 & 1011 & 1561 & 1804 & 2155 & 871 & 523 & 704 & 811 & 771 & 725 & 13 & 29 & 5 & 21 & 71 & 79 & 73 \\
\hline Poland & 0 & 0 & 59 & 348 & 695 & 784 & 849 & 349 & 438 & 555 & 949 & 955 & 856 & 876 & 349 & 437 & 550 & 946 & 947 & 845 & 864 \\
\hline Italy & 0 & 0 & 177 & 706 & 510 & 664 & 771 & 311 & 506 & 286 & 280 & 436 & 445 & 397 & 6 & 36 & 4 & 20 & 12 & 14 & 17 \\
\hline Portugal & 0 & 0 & 0 & 280 & 317 & 321 & 347 & 95 & 52 & 7 & 14 & 20 & 9 & 8 & 0 & 0 & 0 & 0 & 0 & 0 & 0 \\
\hline Finland & 0 & 0 & 0 & 297 & 431 & 281 & 339 & 69 & 53 & 77 & 158 & 55 & 53 & 30 & 69 & 53 & 77 & 158 & 55 & 53 & 30 \\
\hline Sweden & 0 & 0 & 7 & 111 & 124 & 259 & 323 & 169 & 48 & 82 & 110 & 95 & 97 & 99 & 169 & 48 & 82 & 110 & 95 & 97 & 99 \\
\hline Belgium & 0 & 0 & 0 & 309 & 223 & 227 & 229 & 4 & 5 & 6 & 11 & 11 & 11 & 11 & 4 & 5 & 6 & 11 & 11 & 11 & 11 \\
\hline Austria & 0 & 17 & 37 & 237 & 303 & 206 & 255 & 148 & 90 & 87 & 114 & 113 & 130 & 124 & 59 & 52 & 35 & 54 & 38 & 41 & 32 \\
\hline Others & 0 & 60 & 155 & 763 & 889 & 1099 & 1236 & 2107 & 2927 & 3522 & 4639 & 4852 & 5329 & 5179 & 447 & 819 & 964 & 2215 & 1799 & 2331 & 2005 \\
\hline UE 27 & 0 & 564 & 2447 & 8677 & 10,878 & 12,422 & 12,936 & 7940 & 8088 & 8453 & 10,675 & 10,893 & 11,299 & 10,551 & 2684 & 3744 & 4301 & 6464 & 5815 & 6318 & 5211 \\
\hline
\end{tabular}

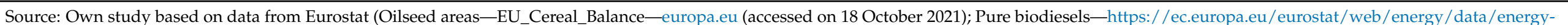
balances (accessed on 18 October 2021). 
Rapeseed remains the dominant raw material used for the production of biofuels (France, Germany, Poland), but its share is systematically decreasing. In 2008, it was $72 \%$, and in 2019, it was only $43 \%$. This is the result of the growing use of used cooking oil (UCO) and palm oil. In 2019, the share of UCO was $21 \%$, and it was mainly used in the Netherlands, Portugal, and Austria. The high biodiesel production in the Netherlands, Portugal and Belgium is based on imports. The incentive for its application is provided by Annex IX, point B of the RED and RED II Directives. In determining the contribution of biofuels to the final energy consumption of the transport sector, the use of UCO can be considered equivalent to twice the energy value of biofuels products from UCO. Palm oil, which had a share of $16 \%$ in 2019 , has been used on a large scale in Spain, Italy, France, and the Netherlands. It has been used on a smaller scale in Finland, Germany, and Portugal. In the EU, biodiesel is also produced from sunflower seeds (Greece, Bulgaria, Hungary, Lithuania, France, Romania, Austria), animal fats (Denmark, Finland, France, The Netherlands), tall oil (Finland, Sweden), and cottonseed oil (Greece). The volume of biodiesel production supplies about $80 \%$ of the demand for this biofuel, hence the need for imports. The EU mostly imports biodiesel from Argentine, Malaysia, China, and Indonesia.

\subsection{Biodiesel Production and Changes in the Area under Basic Crops}

In the EU, the main raw material used for the production of first-generation biodiesel are oilseeds, so as demand for this type of biofuel increases, so does the area under cultivation. Based on tests that were performed independently - using the Pearson correlation-it was found that both the sown areas of oilseed plants (Y1), rapeseed and colza seed (Y2), soybean (Y3), and sunflower (Y4) were significantly correlated to biodiesel production (x). As expected, these correlations were positive, but their strength was characterised by significant differentiation. The characteristics of the estimated parameters of the models are summarised in Table 2. The model expressing the relationship between rapeseed and colza seeding areas $(\mathrm{Y} 2)$ and biodiesel production $(\mathrm{x})$, followed by $\mathrm{Y} 1(\mathrm{x}), \mathrm{Y} 3(\mathrm{x})$, and $\mathrm{Y} 4(\mathrm{x})$, turned out to be the best suited to empirical data $(R 2=0.909)$. Among the EU countries, the production of biodiesel to the greatest extent produced determined the sown area of oilseed crops in Poland $(\mathrm{R} 2=0.803)$.

Table 2. Basic statistic relationships between oilseeds $\left(\mathrm{Y}_{1}\right)$, rape areas $\left(\mathrm{Y}_{2}\right)$, soybean $\left(\mathrm{Y}_{3}\right)$, sunflower $\left(\mathrm{Y}_{4}\right)$, and biodiesel production (x) in UE, Germany, France, and Poland.

\begin{tabular}{|c|c|c|c|c|c|c|c|c|c|c|c|c|c|c|c|c|c|c|}
\hline \multirow[b]{2}{*}{$\begin{array}{c}\text { Dependent } \\
\text { Variable }\end{array}$} & \multicolumn{4}{|c|}{$b_{0}$} & \multicolumn{4}{|c|}{$b_{1}$} & \multicolumn{4}{|c|}{$b_{2}$} & \multicolumn{4}{|c|}{$b_{3}$} & \multirow{2}{*}{$\begin{array}{c}\text { Error } \\
\text { Variance }\end{array}$} & \multirow[b]{2}{*}{$\mathrm{R}^{2}$} \\
\hline & Estimate & $\begin{array}{l}\text { Stan. } \\
\text { Error }\end{array}$ & t-Stat. & $\begin{array}{c}p- \\
\text { Value }\end{array}$ & Estimate & $\begin{array}{l}\text { Stan. } \\
\text { Error }\end{array}$ & t-Stat. & $\begin{array}{c}p- \\
\text { Value }\end{array}$ & Estimate & $\begin{array}{l}\text { Stan. } \\
\text { Error }\end{array}$ & t-Stat. & $\begin{array}{c}p- \\
\text { Value }\end{array}$ & Estimate & $\begin{array}{l}\text { Stan. } \\
\text { Error }\end{array}$ & t-Stat. & $\begin{array}{c}p- \\
\text { Value }\end{array}$ & & \\
\hline \multicolumn{19}{|c|}{ UE } \\
\hline $\mathrm{Y}_{1}$ & 8162.552 & 112.46 & 72.580 & 0.000 & - & - & - & - & 0.00007 & 0.000 & 9.169 & 0.000 & 0.000 & 0.000 & -6.892 & 0.000 & 168205 & 0.904 \\
\hline$Y_{2}$ & 3151.389 & 122.87 & 25.648 & 0.000 & 0.647 & 0.062 & 10.456 & 0.000 & -0.00004 & 0.000 & -7.153 & 0.000 & 0.000 & - & -0.072 & - & 140047 & $\begin{array}{l}0.909 \\
\end{array}$ \\
\hline$Y_{3}$ & 516.030 & 33.412 & 15.444 & 0.000 & -0.034 & 0.011 & -3.158 & 0.004 & - & - & - & - & 0.000 & 0.000 & 5.861 & 0.000 & 11564 & 0.711 \\
\hline $\mathrm{Y}_{4}$ & 4404.115 & 112.99 & 38.977 & 0.000 & -0.474 & 0.123 & -3.862 & 0.001 & 0.000082 & 0.000 & 3.550 & 0.002 & 0.000 & 0.000 & -3.133 & 0.005 & 83821 & 0.359 \\
\hline \multicolumn{19}{|c|}{ Germany } \\
\hline$Y_{1}$ & 995.231 & 44.249 & 22.492 & 0.000 & 0.375 & 0.065 & 5.776 & 0.000 & - & - & - & - & & & -4.682 & 0.000 & 16693 & 0.587 \\
\hline $\mathrm{Y}_{2}$ & 995.231 & 44.249 & 22.492 & 0.000 & 0.375 & 0.065 & 5.776 & 0.000 & - & - & - & - & & & -4.682 & 0.000 & 16693 & 0.587 \\
\hline \multicolumn{19}{|c|}{ France } \\
\hline$Y_{1}$ & 1764.149 & 64.072 & 27.534 & 0.000 & 0.603 & 0.187 & 3.225 & 0,003 & -0.00019 & 0.000 & -2.403 & 0.024 & & & & - & 22705 & 0.515 \\
\hline$Y_{2}$ & 623.984 & 86.412 & 7.221 & 0.000 & 2.057 & 0.402 & 5.118 & 0.000 & -0.00134 & 0.000 & -3.600 & 0.001 & 0.000 & 0.000 & 2.650 & 0.014 & 20948 & 0.752 \\
\hline \multicolumn{19}{|c|}{ Poland } \\
\hline $\mathrm{Y}_{1}$ & 461.034 & 26.846 & 17.173 & 0.000 & 1.547 & 0.242 & 6.392 & 0.000 & -0.00127 & 0.000 & -4.206 & 0.000 & - & - & - & - & 10013 & 0.803 \\
\hline$Y_{2}$ & 459.682 & 26.706 & 17.213 & 0.000 & 1.549 & 0.241 & 6.435 & 0.000 & -0.00129 & 0.000 & -4.281 & 0.000 & - & - & - & - & 9909 & 0.800 \\
\hline
\end{tabular}

Source: Own study based on data from Eurostat (EU_Cereal_Balance-europa.eu (accessed on 18 October 2021); Pure biodiesels_https:/ / ec.europa.eu/eurostat/web/energy/data/energy-balances (accessed on 18 October 2021).

These relationships are reflected in changes in the sown areas of basic crops (Figure 2). The sowing area of oilseeded crops, with the exception of sunflower, increased, and the sowing area of cereals decreased (except for triticale). Trend models for the sowing of basic crops and their statistical characteristics are presented in Table 3. The estimated trend models for the sown area of oilseed crops, including oilseed rape, cereals (except wheat 
and maize for grain), and biofuels (except other liquid biofuels), are very well fitted to the characterised phenomena ( $R^{2}$ for the mentioned variables ranges from 0.754 to 0.916 ).

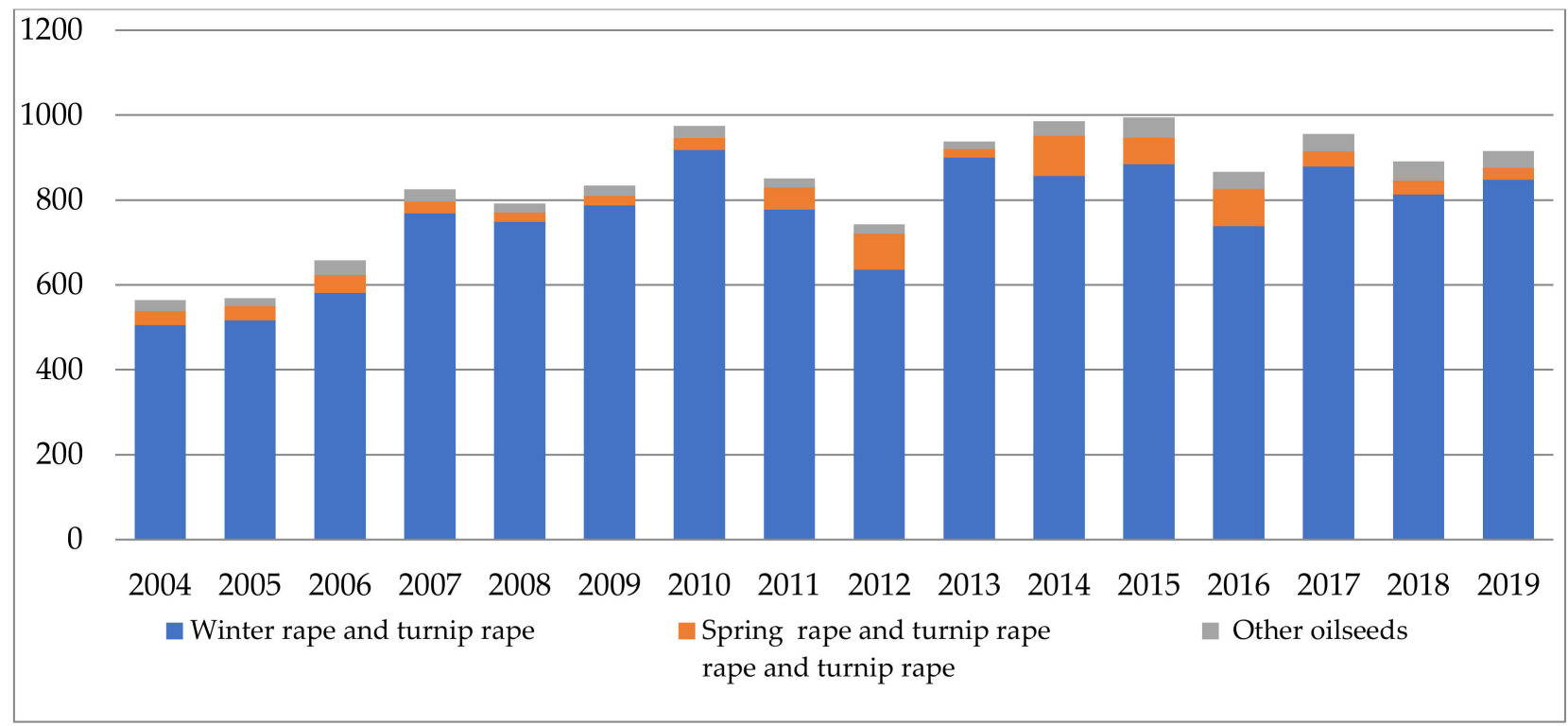

Figure 2. Sown area of oilseed crops in Poland in 2004-2019 (per thousand hectares).

Table 3. Linear trend models for the sowing of major crops and selected biofuels and their statistical characteristics.

\begin{tabular}{|c|c|c|c|c|c|c|}
\hline \multirow{2}{*}{ Scheme 1} & \multicolumn{4}{|c|}{$b_{1}$ Parameter Characteristic } & \multirow{2}{*}{$\begin{array}{c}\text { Error } \\
\text { Variance }\end{array}$} & \multirow{2}{*}{$\begin{array}{l}\text { Adjusted } \\
\text { R-Squared }\end{array}$} \\
\hline & Estimate & Stan. Error & t-Stat. & $p$-Value & & \\
\hline Total oilseeds & 0.144 & 0.014 & 10.358 & 0.000 & 0.354 & 0.797 \\
\hline Rape and turnip rape & 0.131 & 0.014 & 9.148 & 0.000 & 0.377 & 0.754 \\
\hline Soybean & 0.015 & 0.004 & 3.798 & 0.001 & 0.027 & 0.332 \\
\hline Sunflower & -0.002 & 0.009 & -0.194 & 0.847 & 0.136 & -0.037 \\
\hline Total cereals & -0.233 & 0.029 & -8.063 & 0.000 & 1,526 & 0.703 \\
\hline Wheat & 0.021 & 0.017 & 1.202 & 0.240 & 0.544 & 0.016 \\
\hline Barley & -0.147 & 0.011 & -13.370 & 0.000 & 0.222 & 0.868 \\
\hline Rye & -0.093 & 0.008 & -11.944 & 0.000 & 0.111 & 0.840 \\
\hline Triticale & 0.060 & 0.006 & 10.427 & 0.000 & 0.061 & 0.800 \\
\hline Oats & -0.031 & 0.003 & -11.756 & 0.000 & 0.013 & 0.836 \\
\hline Grain maize & -0.025 & 0.012 & -2.033 & 0.052 & 0.284 & 0.104 \\
\hline Other cereals & -0.017 & 0.004 & -4.389 & 0.000 & 0.027 & 0.403 \\
\hline $\begin{array}{c}\text { Renewable energy } \\
\text { sources }\end{array}$ & 6.042 & 0.276 & 21.932 & 0.000 & 111.011 & 0.950 \\
\hline Total biofuels & 0.715 & 0.043 & 16.506 & 0.000 & 2.744 & 0.916 \\
\hline Pure biodiesels & 0.570 & 0.035 & 16.082 & 0.000 & 1.834 & 0.912 \\
\hline Pure biogasoline & 0.119 & 0.008 & 14.053 & 0.000 & 0.105 & 0.887 \\
\hline Other liquid biofuels & 0.026 & 0.008 & 3.155 & 0.004 & 0.102 & 0.264 \\
\hline
\end{tabular}

Source: own study based on data from Eurostat (EU_Cereal_Balance—europa.eu (accessed on 18 October 2021) Pure biodiesels—https: // ec.europa.eu/eurostat/web/energy/data/energy-balances (accessed on 18 October 2021). 
Linear models turned out to be the most fitted, except for in the case of the sown area of total oilseed crops and oilseed rape and colza. For the total oilseed crops and for oilseed rape and colza, these were quadratic trends (Table 4). These trends were characterised by a very high coefficient of determination $\left(R^{2}=0.926\right)$, which may indicate that the used model is correct.

Table 4. Quadratic trend models for total oilseed crops and oilseed rape and colza area and their statistical characteristics.

\begin{tabular}{|c|c|c|c|c|c|c|c|c|c|c|}
\hline \multirow[b]{2}{*}{ Specification } & \multicolumn{4}{|c|}{$\mathrm{b}_{1}$ Parameter Characteristic } & \multicolumn{4}{|c|}{$\mathrm{b}_{2}$ Parameter Characteristic } & \multirow[b]{2}{*}{$\begin{array}{c}\text { Error } \\
\text { Variance }\end{array}$} & \multirow[b]{2}{*}{$\begin{array}{c}\text { Adjusted } \\
\text { R-Squared }\end{array}$} \\
\hline & Estimate & $\begin{array}{l}\text { Stan. } \\
\text { Error }\end{array}$ & & & Estimate & $\begin{array}{l}\text { Stan. } \\
\text { Error }\end{array}$ & t-Stat. & $\begin{array}{c}p- \\
\text { Value }\end{array}$ & & \\
\hline $\begin{array}{c}\text { Total } \\
\text { oilseeds }\end{array}$ & 0.507 & 0.054 & 9.467 & 0.000 & -0.016 & 0.002 & -6.296 & 0.000 & 0.108 & 0.926 \\
\hline $\begin{array}{l}\text { Rape and } \\
\text { turnip rape }\end{array}$ & 0.490 & 0.065 & 7.518 & 0.000 & -0.018 & 0.003 & -5.995 & 0.000 & 0.159 & 0.817 \\
\hline
\end{tabular}

Source: own study based on data from Eurostat (EU_Cereal_Balance-europa.eu (accessed on 18 October 2021); Pure biodieselshttps:/ / ec.europa.eu/eurostat/web/energy/data/energy-balances (accessed on 18 October 2021).

\section{Materials and Methods}

The analyses in Section 2.4 show that the implementation of the EU biofuel policy has contributed to a significant increase in oilseed sowing. In Poland, the average acreage occupied by these crops in 2017-2019 was more than 58\% higher than the 2004-2006 average (Table 5). Hence, it was first necessary to identify the crop species that were abandoned in favour of oilseed crops. To this end, statistical relations between the areas sown to oilseed crops (Y1) and the areas taken up by other crops (xn) were evaluated. In the next stages, on the basis of research conducted at the Institute of Plant Cultivation, Fertilisation and Soil Science National Research Institute in Puławy (IUNG PIB), the Institute of Agricultural and Food Economics National Research Institute in Warsaw (IERiGŻ PIB), literature on the subject, and data from the Central Statistical Office, the following five factors were identified and quantified, and it was on the basis of this that a synthetic assessment of the economic benefits of increasing the area of oilseed crop cultivation in Poland was made:

- The sown area of oilseeds;

- The area of sown crops replaced by oilseeds;

- The direct surplus for the above-mentioned crops;

- The value of oilseeds as a forecrop in relation to the crops that were replaced;

- The profits of beekeeping;

- The possibilities of using by-products for feed purposes and thereby reducing protein feed imports.

Table 5. Changes in the sown area of main crops in Poland in 2004-2019 (per thousand hectares).

\begin{tabular}{|c|c|c|c|}
\hline \multirow{2}{*}{ Specification } & \multicolumn{2}{|c|}{ Average } & \multirow{2}{*}{ Difference } \\
\hline & 2004-2006 & $2017-2019$ & \\
\hline Wheat (winter) & 1848.2 & 1972.8 & 124.6 \\
\hline Wheat (spring) & 386.7 & 467.3 & 80.6 \\
\hline Barley(winter) & 143.0 & 205.7 & 62.7 \\
\hline Triticale (winter) & 1032.7 & 1137.2 & 104.5 \\
\hline Triticale (spring) & 114.9 & 181.0 & 66.1 \\
\hline Maize for grain & 353.5 & 624.1 & 270.6 \\
\hline Maize for feed & 317.4 & 599.2 & 281.8 \\
\hline
\end{tabular}


Table 5. Cont.

\begin{tabular}{|c|c|c|c|}
\hline \multirow{2}{*}{ Specification } & \multicolumn{2}{|c|}{ Average } & \multirow{2}{*}{ Difference } \\
\hline & 2004-2006 & $2017-2019$ & \\
\hline $\begin{array}{l}\text { Rape and turnip rape } \\
\text { (winter) }\end{array}$ & 534.6 & 846.6 & 312.0 \\
\hline Total & 4731.0 & 6033.9 & 1302.9 \\
\hline Rye & 1427.6 & 890.3 & -537.3 \\
\hline Barley (spring) & 972.9 & 762.4 & -210.5 \\
\hline $\begin{array}{l}\text { Cereal mixed for } \\
\text { grain (spring) }\end{array}$ & 1412.6 & 861.8 & -550.8 \\
\hline Potatoes & 632.9 & 311.7 & -321.2 \\
\hline Sugar beets & 286.9 & 237.1 & -49.8 \\
\hline Total & 4732.9 & 3063.3 & -1669.6 \\
\hline
\end{tabular}

\section{Results and Discussion}

\subsection{Land Use Change}

In the years 2004-2019, the sown area of oilseed crops in Poland increased from 564.8 thousand ha to 915.9 thousand ha. Rapeseed and winter oilseed rape accounted for the largest share in the structure of these crops, from $85.2 \%$ in 2016 to $95.9 \%$ in 2013, with the average for the whole period under study being $91.0 \%$ (Figure 2).

In the same period, the total sown area decreased from 11,285.4 thousand ha to 10,897.7 thousand ha. Apart from the decrease in the sown area, there were significant changes in its structure. Apart from rapeseed and colza, maize, wheat, and triticale areas increased to the greatest extent. These plant species were mainly introduced in place of spring cereal mixtures, rye, potatoes, and spring barley (Table 5). Similar trends were observed in most EU countries [100,109-111]. The main reason or this was the profitability of production [96-98,100,112].

In order to illustrate these changes in relation to oilseed rape and colza seed, causeand-effect models were built and subjected to detailed verification, where the dependent variable was the area sown with oilseed rape and colza seed, and the independent variables were the areas of other crops, and these models were constructed using the following procedure:

- The model was estimated with all of the independent variables and then statistically insignificant and non-coincident variables were removed by a posteriori elimination method;

- The model was estimated using all of the independent variables as potential variables using the stepwise regression algorithm (assuming that the variable left in the model must be statistically significant at least at the level of $p<0.05$ ) and following the rule of coincidence;

- The model with independent variables negatively correlated with the dependent variable was estimated, and then statistically insignificant and non-correlated variables were removed by a posteriori elimination method;

- The model was estimated by using only independent variables as the potential variables for winter crops, which were negatively correlated with the dependent variables, using the stepwise regression algorithm (assuming that the variable left in the model must be statistically significant at least at the level of $p<0.05$ ) and following the rule of coincidence;

- The dependence model of the sown area of winter rape and colza (Y) and rye (X) was estimated with the use of an additional artificial zero-one variable (with value 1 for the periods when the variable $\mathrm{Y}$ had significantly lower values than those resulting 
from the linear model; and 0-in the remaining periods). Both variables in the model were statistically significant at the $p<0.0001$ level.

The obtained econometric models, whose parameters were estimated with the use of the Classic Least Squares Method, were subjected to further verification to assess their quality and the validity of their specification (e.g., tests of non-linearity, RESET specification, stability of QUSUM parameters, distribution of residuals). Finally, the selected models were characterised by the best values of the corrected coefficient of determination and the Akaike information index. No significant residual autocorrelation was found in the approximated models (LM test for autocorrelation of order 1). Due to a small number of observations, testing integration and the cointegration of the examined time series was abandoned. The only variable fulfilling these conditions was the winter rye sown area. The trend of decreasing the share of this crop in the sowing structure has persisted since the second half of the 1960s. Between 1965 and 2015 in Poland, the share of rye in the cereal sowing structure decreased from $52.8 \%$ to $9.7 \%$. Initially, its place was taken by wheat and rye, and since 2004, its share has also been replaced by oilseed rape [113]. The introduction of oilseed rape to crops was regionally differentiated and depended on the share of good soil and the structural area of farms [114]. Stable oilseed rape yields can only be obtained in good and very good soils, which constitute about 50\% of the arable land in Poland. Moreover, only larger farms can apply the correct technology needed for the production of the seeds of this plant. At present, over $70 \%$ of rape crops are grown in farm with over 50 ha of arable land.

\subsection{Revenues of Operations}

As a principle, the activities of agricultural producers aim to obtain the highest possible income from their activities. This is true outside of Poland as well, with the key factor being based on which farmers made decisions to increase the production of winter oilseed rape and colza due to its higher profitability in relation to most cereal crops, especially winter ones [96-98,100,101,112]. Table 6 compares the average incomes obtained from the production of winter oilseed rape and rapeseed as well as rye, triticale, and winter wheat in 2013-2019. These values were determined within the framework of the AGROKOSZTY and Polish FADN agricultural product data collection system conducted at the Institute of Agricultural Economics and Food Economics-National Research Institute in Warsaw, in cooperation with agricultural advisory centres. Over the entirety of the analysed period, the income obtained from the production of winter oilseed rape and colza was significantly higher than that of winter rye (by 59.7\%) and triticale (by 29.4\%) and was comparable to winter wheat $[96-99,115,116]$.

Table 6. Income from production of winter rape and colza, rye, triticale, and wheat in 2013-2019 (PLN/ha).

\begin{tabular}{ccccccccc}
\hline Specification & $\mathbf{2 0 1 3}$ & $\mathbf{2 0 1 4}$ & $\mathbf{2 0 1 5}$ & $\mathbf{2 0 1 6}$ & $\mathbf{2 0 1 7}$ & $\mathbf{2 0 1 8}$ & $\mathbf{2 0 1 9}$ & $\begin{array}{c}\text { Average } \\
\mathbf{2 0 1 3}-\mathbf{2 0 1 9}\end{array}$ \\
\hline $\begin{array}{c}\text { Rape and } \\
\text { turnip rape } \\
\text { (winter) }\end{array}$ & 2147 & 2225 & 2077 & 1508 & 1793 & 1918 & 2050 & 1960 \\
\hline Wheat (winter) & 2177 & 2247 & 1982 & 1409 & 1945 & 1975 & 1739 & 1925 \\
\hline Rye (winter) & 1273 & 1480 & 1252 & 1186 & 1446 & 1166 & 1137 & 1227 \\
\hline $\begin{array}{c}\text { Triticale } \\
\text { (winter) }\end{array}$ & 1624 & 1724 & 1387 & 1411 & 1568 & 1452 & 1427 & 1513 \\
\hline
\end{tabular}

Source: Own study on the basis of statistic belongings to the Institute of Agricultural and Food EconomicsNational Research Institute in Warsaw, Poland.

\subsection{Pre-Crop Value}

Apart from the financial benefits, oilseed rape cultivation is distinguished by a whole range of other favourable characteristics that are important for farms. The most important 
of these is its value as a forecrop, especially on farms specialising in cereal production. The cultivation of oilseed rape enables the effective interruption of the natural development cycle of cereal plant diseases and prevents the spread of weeds and pests. This makes the management of successive cereal crops easier, which helps to increase yields and reduce cultivation costs [100,101,103]. In addition, soil cover for 11 months of the year and a deep and extensive root system counteract erosion, improve soil aeration, and reduce nitrate leaching. The large amounts of biomass produced by oilseed rape both above and below the soil surface also contribute to the build-up of fertile humus [102].

In Poland, oilseed rape is mainly grown in simplified crop rotations (3-field rotations) after cereals, and it is most often the only crop that interrupts the succession of cereals. If oilseed rape is excluded from crop rotation, its place will be taken by cereals with greater economic value, mainly winter wheat, and that can be grown in weaker soils-triticale or rye. This situation will cause a deterioration in the value of the site for cereal cultivation and will generally result in lower yields. It is assumed that wheat yields are $15-20 \%$ higher in the stand after rape compared to pre-crops. Many years of research indicate that a negative stand for cereal cultivation cannot be fully compensated by increased fertilisation or higher doses of plant protection products [117]. The effect of lower yield of cereals under the conditions of the increased cereal shares in the sowing structure should be associated with the deterioration of phytosanitary conditions (increased intensity of diseases of the stem base and root system), weed infestation in the field (including possible compensation of noxious weeds), and the accumulation of toxic phenolic compounds in the soil [99-104].

The expanding cultivation area is also a factor stimulating the yield level of wheat, which both in Poland and in the world is traditionally sown in the position after rape [118]. The important significance of oilseed rape as a forecrop for cereals also results from its favourable effect on the soil environment under cultivation conditions, especially in terms of long monoculture sequences of monocotyledonous vegetation [119]. The attractiveness of winter oilseed rape as a forecrop is not only due to the rapid decomposition of crop residues (narrow $\mathrm{C}: \mathrm{N}$ ratio) but is also due to their biofumigant effects [120]. Manfred Schoepe [96] estimated the value of a post-rape stand at $130 \mathrm{EUR} / \mathrm{ha}$. In the presented paper, these values for wheat, triticale, and rye were set being equivalent to $11 \%$ of the yield (Table 7). Such an assumption was based on the results of research conducted in IUNG PIB [102,117,121,122] and in the literature [96,100,101,103,104].

Table 7. Average yields and prices of grain wheat, triticale, rye, and pre-crop value after rape in 2013-2019.

\begin{tabular}{cccccc}
\hline \multirow{2}{*}{ Specification } & Yield & \multicolumn{2}{c}{ Prices } & \multicolumn{2}{c}{ Pre-Crop Value } \\
\cline { 3 - 6 } & Mg/ha & PLN/Mg & EUR/Mg & PLN & EUR \\
\hline $\begin{array}{c}\text { Wheat } \\
\text { (winter) }\end{array}$ & 6.3 & 654.2 & 149.7 & 453.4 & 103.7 \\
\hline Rye (winter) & 3.5 & 530.3 & 121.4 & 204.2 & 46.7 \\
\hline $\begin{array}{c}\text { Triticale } \\
\text { (winter) }\end{array}$ & 4.8 & 534.4 & 122.3 & 282.2 & 64.6 \\
\hline
\end{tabular}

Source: Own study on the basis of statistic belongings of Institute of Agricultural and Food Economics-National Research Institute in Warsaw, Poland.

\subsection{Profits from Beekeeping}

Beekeeping is a very important part of the bioeconomy. However, the literature is dominated by studies on the ecosystem services provided by pollinators. According to estimates made by Launtenbach and associates [123], the global value of pollinator services in 2009 was EUR 265 billion. In Europe, the largest benefits were obtained in Italy, Greece, Spain, France, the UK, Germany, the Netherlands, Switzerland, Austria, Poland, Romania, and Hungary. The latest published estimates on the value of the ecosystem service provided to the human economy by pollinators, mainly by honeybees, puts this work at between USD 235 and 577 billion. These values may vary depending on the assessment method used 
and the inflation levels that are assumed. It is worth noting that successive evaluations of pollination benefits to the food economy become higher and higher [124,125]. In Poland, the economic value of bees as pollinators of crop plants alone was estimated to be around EUR 2.0 billion in 2015 [126].

Agriculture, however, mainly through so-called melliferous plants, can contribute to the development of apiary management. The beekeeping value of a given plant species is mainly determined by the time and abundance of flowering as well as by the abundance of nectar and pollen. Winter oilseed rape is an excellent source of honey in the first two decades of May and is classified as a commodity crop, i.e., one from which significant quantities of honey can be obtained. The flowering period of oilseed rape lasts, depending on weather conditions, from 15 to 20 days, during which flowering plants provide insects with approximately $90-120 \mathrm{~kg}$ of sugars and $115-160 \mathrm{~kg}$ of pollen from 1 hectare of crops [127-129]. The high beekeeping value of oilseed rape is evidenced by the intensity of its flight by pollinating insects, reaching up to $5-6$ individuals per $1 \mathrm{~m}^{2}$ of the flowering canopy in the peak insect flight hours in good weather, among which the honeybee constitutes approximately $90 \%$ of all of the insects found on flowers [130]. The value of net profit of beekeeping (the calculation as food fields for apiculture) from one hectare of oilseed rape cultivation was determined on the basis of research conducted at the Apiculture Division in Pulawy of to The National Institute of Horticultural Research, at the level of $55 \mathrm{EUR} / \mathrm{ha}$. This amount is similar to that estimated by the Institute for Economic Research at the University Munich [96].

\section{Conclusions}

In Poland, rapeseed production has been the fastest growing branch of plant production since the year 2000. Rapeseed yields have increased 2.5 times in the last 20 years. The main reason for this trend was the implementation of obligations resulting from legal acts by Member States relating to increasing the share of RES in the structure of primary energy production and to the share of biofuels in fuels used in transport in particular. In the White Paper, which was entitled "Energy for the Future: renewable sources of energy", prepared by the European Commission in 1997, it was indicated that the fulfilment of these intentions would take place through the increased production of first-generation biofuels, mainly biodiesel produced from rapeseed.

In Poland, in the years 2010-2020, about 1.0-1.6 million tons of rapeseed was used for this purpose annually. Such utilization had an impact on the increase in agricultural incomes, contributed to the decrease in income disparity, and increased the chances of gaining equal-with respect to urban residents-access to goods and services. Moreover, an increase in the demand for agricultural raw materials for biofuel production created an opportunity to abolish the demand barrier that hampers the development of agriculture. Another important benefit connected to the development of the liquid biofuel sector is the processing of oilseed, thanks to which the country obtains considerable quantities of high-protein post-extraction meal, which is an important component of feedstuffs. This makes it possible to limit imports of high-protein feedstuffs, mainly soya meal, including that produced from genetically modified seeds.

Due to the fact that biofuel production competes for raw materials with the food economy, at the end of the first decade of the 21st century, many called for withdrawal from the policy supporting the biofuel sector. Its implementation was to lead, inter alia, to changes in land use, mainly in the reduction of the area comprising forests and land with natural values. The research conducted here shows that in Poland in the period 2000-2020, the opposite trend occurred. The area of forest land increased from 9.1 to 9.6 million hectares, including increases in the area taken up by forests from 8.9 to 9.3 million hectares, and the sown area decreased from 12.4 to 10.8 million hectares despite a significant increase in rape sowing from 437 to 864 thousand hectares. The introduction of changes in the present EU biofuel policy may result in a significant reduction in the area where oilseed rape is sown and thus in a reduction in the income generated from its production. 
Taking into account the factors determining the cultivation of oilseed rape: soil quality, the share in the sowing structure of farms, the area structure of farms, and regionalisation related to the risk of crop freezing, it can be assumed that the growth and production of oilseed rape will be abandoned first by farms that produce the crop on land that is less suitable for oilseed rape production, e.g., medium soils (complex 5) and some good soils (complexes 8,11 ), as well as smaller farms. Only in good and very good soils, which in Poland constitute around $50 \%$, and on larger farms (over 50 ha) can a smaller reduction in rape growing area be expected. Rape will be replaced in the sowing structure by rye, triticale, and, in good soils, wheat. Compared to oilseed rape, their production is characterised by lower income per hectare; in 2013-2019 these differences amounted to EUR 8 for wheat, EUR 102.3 for triticale, and EUR 168 for rye.

The expanding area of rape cultivation is a factor stimulating the yield level of other plants, mainly wheat, which both in Poland and worldwide is traditionally sown in the position after rape. The significant importance of oilseed rape as a forecrop for cereal crops results from its favourable impact on the soil environment in terms of cultivation conditions and long monoculture sequences of monocotyledonous vegetation. At present, oilseed rape is mainly grown in simplified rotations (3-field) after cereals, and it is usually the only plant that is able to interpret the succession of cereals. If oilseed rape is removed from the rotation, cereals will take its place. This situation will cause the value of the growing area used to grow cereals to decrease and thus a decrease in the yield of those cereals. On the basis of the conducted research, the estimated value of oilseed rape as a fore crop for wheat, triticale, and rye was EUR 103.7, 64.6, and 46.7, respectively. An additional advantage of oilseed rape is that it is an excellent bee resource and is classified as a commodity crop, i.e., one from which significant amounts of honey can be obtained, with a net value of EUR 55 per hectare.

In addition, in many agricultural holdings, as a result of the forecasted changes in crop production, there will be an accumulation in field work during the harvest period, which will also affect the worse use of machinery and storage areas. The consequence of increasing the acreage of cereal cultivation and its supply may be worse production profitability and thus the income situation of farms, but this will be assessed at the next stage of research.

Author Contributions: Conceptualization, P.G.; methodology, P.G. and K.J.; software, P.G. and K.J.; validation, P.G. and B.G.; formal analysis, M.W. and P.G.; investigation, P.G. and A.T.; resources, P.G.; data duration, P.G. and B.G.; writing-original draft, P.G., K.J., M.W., A.W., B.G. and A.T.; writing-review and editing, K.J., M.W., B.G., P.G., A.T. and A.W.; supervision, P.G., K.J. and M.W.; funding acquisition, P.G. and A.W. All authors have read and agreed to the published version of the manuscript.

Funding: This research received no external funding.

Institutional Review Board Statement: Not applicable.

Informed Consent Statement: Not applicable.

Data Availability Statement: Not applicable.

Conflicts of Interest: The authors declare no conflict of interest.

\section{References}

1. Songstad, D.D.; Lakshmanan, P.; Chen, J.; Gibbons, W.; Hughes, S.; Nelson, R. Historical perspective of biofuels: Learning from the past to rediscover the future. In Vitro Cell. Dev. Biol. Plant 2009, 45, 189-192. [CrossRef]

2. Ayadi, M.; Sarma, S.J.; Pachapur, V.L.; Brar, S.K.; Cheikh, R.B. History and Global Policy of Biofuels. In Green Fuels Technology; Soccol, C.R., Brar, S.K., Faulds, C., Ramos, L.P., Eds.; Springer International Publishing: Cham, Switzerland, 2016 ; pp. 1-14. [CrossRef]

3. Singh, R.S.; Pandey, A.; Gnansounou, E. Biofuels: Production and Future Perspectives; CRC Press, Taylor \& Francis Group: Boca Raton, FL, USA, 2016; ISBN 978-149-872-359-6.

4. Knothe, G. The History of Vegetable Oil-Based Diesel Fuels. In The Biodiesel Handbook, 2nd ed.; Knothe, G., Krahl, J., Gerpen, J.V., Eds.; AOCS Press: Urbana, IL, USA, 2010; pp. 5-19. [CrossRef] 
5. Ma, F.; Hanna, M.A. Biodiesel production: A review. Bioresour. Technol. 1999, 70, 1-15. [CrossRef]

6. Ghobadian, B.; Rahimi, H.; Nikbakht, A.M.; Najafi, G.; Yusaf, T.F. Diesel engine performance and exhaust emission analysis using waste cooking biodiesel fuel with an artificial neural network. Renew. Energy 2009, 34, 976-982. [CrossRef]

7. Carolan, M.S. A Sociological Look at Biofuels: Ethanol in the Early Decades of the Twentieth Century and Lessons for Today. Rural. Sociol. 2009, 74, 86-112. [CrossRef]

8. Solomon, B.D.; Barnes, J.R.; Halvorsen, K.E. Grain and cellulosic ethanol: History, economics, and energy Policy. Biomass Bioenergy 2007, 31, 416-425. [CrossRef]

9. Balat, M.; Balat, H.; Öz, C. Progress in bioethanol processing. Prog. Energy Combust. Sci. 2008, 34, 551-573. [CrossRef]

10. Rosillo-Calle, F.; Walter, A. Global market for bioethanol: Historical trends and future prospects. Energy Sustain. Dev. 2006, 10, 20-32. [CrossRef]

11. Kovarik, B. Henry Ford, Charles, F. Kettering and the Fuel of the Future. Automot. Hist. Rev. Spring 1998, 32, 7-27. Available online: https:/ / environmentalhistory.org/people/henry-ford-charles-kettering-and-the-fuel-of-the-future/ (accessed on 14 November 2020).

12. Dimitri, C.; Effland, A. Fueling the automobile: An economic exploration of early adoption of gasoline over ethanol. J. Agric. Food Ind. Organ. 2007, 5, 1-21. [CrossRef]

13. Yergin, D. The Prize: The Epic Quest for Oil Money and Power; Simon and Schuster: New York, NY, USA, 1991; ISBN 0-671-50248-4.

14. BP. Statistical Review of World Energy, 69th ed.; 2020. Available online: https://www.bp.com/content/dam/bp/businesssites/en/global/corporate/pdfs/energy-economics/statistical-review/bp-stats-review-2020-full-report.pdf (accessed on 16 November 2020).

15. Toffler, A. The Third Wave; Bantam Books: New York, NY, USA, 1980; ISBN 0-553-24698-4.

16. Energy Information Agency, U.S. Department of Energy, Washington. International Energy Outlook 2003. Available online: https:/ / www.hsdl.org/?view\&did=15902 (accessed on 14 November 2020).

17. International Energy Agency. Statistics Report. Key World Energy Statistics 2020. Available online: https://webstore.iea.org/ download/direct/4093?fileName=Key_World_Energy_Statistics_2020.pdf (accessed on 18 November 2020).

18. Soddy, F. Wealth, Virtual Wealth and Debt. The Solution of the Economic Paradox; Britons Publishing Company: London, UK, 1933; Available online: https: / / www.fadedpage.com/link.php?file=20140873-a5.pdf (accessed on 16 November 2020).

19. Trenn, T.J. The central role of energy in soddy's holistic and critical approach to nuclear science, economics, and social responsibility. Br. J. Hist. Sci. 1979, 12, 261-276. [CrossRef]

20. Csereklyei, Z.; Rubio-Varas, M.d.M.; Stern, D.I. Energy and economic growth: The stylized facts. Energy J. 2016, 37, 223-255. [CrossRef]

21. Stern, D.I.; Kander, A. The role of energy in the industrial revolution and modern economic growth. Energy J. 2012, 33, 125-152. [CrossRef]

22. Jevons, W.S. The Coal Question: An Inquiry Concerning the Progress of the Nation, and the Probable Exhaustion of Our Coal-Mines; Macmillan \& Co.: London, UK, 1865. Available online: https:/ /books.google.pl/books?id=gAAKAAAAIAAJ\&dq=editions: AAotKDT6KKcC\&pg=PR3\&redir_esc=y\&hl=pl\#v=onepage\&q\&f=false (accessed on 20 November 2020).

23. Dasgupta, P.; Heal, G. The optimal depletion of exhaustible resources. Rev. Econ. Stud. 1974, 41, 3-28. [CrossRef]

24. Solow, R.M. Intergenerational equity and exhaustible resources. Rev. Econ. Stud. 1974, 41, 29-45. [CrossRef]

25. Stiglitz, J. Growth with exhaustible natural resources: Efficient and optimal growth paths. Rev. Econ. Stud. 1974, 41, 123-137. [CrossRef]

26. Slade, M. Trends in natural-resource commodity prices: An analysis of the time domain. J. Environ. Econ. Manag. 1982, 9, 122-137. [CrossRef]

27. Stern, D.I. Limits to substitution and irreversibility in production and consumption: A neoclassical interpretation of ecological economics. Ecol. Econ. 1997, 21, 197-215. [CrossRef]

28. Ghasemian, S.; Faridzad, A.; Abbaszadeh, P.; Taklif, A.; Ghasemi, A.; Hafezi, R. An overview of global energy scenarios by 2040: Identifying the driving forces using cross-impact analysis method. Int. J. Environ. Sci. Technol. 2020, 1-24. [CrossRef]

29. U.S. Energy Information Agency. International Energy Outlook 2020 with Projections to 2050. 2020. Available online: https: //www.eia.gov/outlooks/aeo/pdf/aeo2020.pdf (accessed on 19 November 2020).

30. International Renewable Energy Agency. Global Energy Transformation. A Roadmap to 2050. 2018. Available online: https:/ / www.irena.org/-/media/Files/IRENA/Agency/Publication/2018/Apr/IRENA_Report_GET_2018.pdf (accessed on 18 November 2020).

31. Marks-Bielska, R.; Bielski, S.; Pik, K.; Kurowska, K. The importance of renewable energy sources in Poland's energy mix. Energies 2020, 13, 4624. [CrossRef]

32. Hansen, J.; Sato, M.; Ruedy, R.; Lo, K.; Lea, D.W.; Medina-Elizade, M. Global temperature change. Proc. Natl. Acad. Sci. USA 2006, 103, 14288-14293. [CrossRef] [PubMed]

33. Cambridge University Press. Stern Review: The Economics of Climate Change. Available online: http:/ / mudancasclimaticas. cptec.inpe.br/ \{\}rmclima/pdfs/destaques/sternreview_report_complete.pdf (accessed on 10 November 2020).

34. Schipper, L. Conceptual history of adaptation in the UNFCCC process. Rev. Eur. Community Int. Environ. Law 2006, 15, 82-92. [CrossRef] 
35. United Nations. Kyoto Protocol to the United Nations Framework Convention on Climate Change. Available online: https: // unfccc.int/resource/docs/convkp/kpeng.pdf (accessed on 18 November 2020).

36. Report of the Conference of the Parties Serving as the Meeting of the Parties to the Kyoto Protocol on Its Eighth Session, Held in Doha from 26 November to 8 December 2012. Available online: https:/ /unfccc.int/resource/docs/2012/cmp8/eng/13a01.pdf (accessed on 18 November 2020).

37. Blusz, K.; Hinc, A.; Brodzikowski, J. W Kierunku Niskoemisyjnej Strategii Gospodarczej dla Polski. Energia i Klimat Pomiędzy Keynesem i Hayekiem? DemosEUROPA—Centrum Strategii Europejskiej: Warszawa, Poland, 2011.

38. United Nations. Adoption of the Paris Agreement. Available online: https://unfccc.int/resource/docs/2015/cop21/eng/109r01. pdf (accessed on 18 November 2020).

39. Kulovesi, K.; Oberthür, S. Assessing the EU's 2030 Climate and Energy Policy Framework: Incremental change toward radical transformation? Rev. Eur. Comp. Int. Environ. Law 2020, 29, 151-166. [CrossRef]

40. European Commission. Communication from the Commission to the European Parliament, the European Council, the Council, the European Economic and Social Committee and the Committee of the Regions: The European Green Deal. Available online: https:/ / ec.europa.eu/info/sites/info/files/european-green-deal-communication_en.pdf (accessed on 10 November 2020).

41. Bertram, R.B. New crops and the international agricultural research centers. In New Crops; Janick, J., Simon, J.E., Eds.; Wiley: New York, NY, USA, 1993; pp. 11-22. Available online: https:// hort.purdue.edu/newcrop/proceedings1993/V2-011.html (accessed on 10 November 2020).

42. Rexen, F.; Munck, L.; Andersen, F. Cereal Crops for Industrial Use in Europe. Report Prepared for: The Commission of the European Communities; EEC and the Carlsberg Research Laboratory: Copenhagen, Denmark, 1984.

43. Mangan, C.; Kerckow, B. Practical Information and Programmes-Eclair-Agro-Industrial Research-Mid-Term Progress Reports-1988-1993; Commission of the European Communities Directorate-General XII Science-Research-Development, European Commission: Luxembourg, 1994.

44. European Parliament; Directorate General Internal Policies of the Union; Policy Department Structural and Cohesion Policies, Agriculture and Rural Development. The Promotion of Non-Food Crops. 2005. Available online: https://www.europarl.europa.eu/ meetdocs/2004_2009/documents/dv/studynon-foodcrops_/studynon-foodcrops_\%20en.pdf (accessed on 12 November 2020).

45. Hall, D.O.; Overend, R.P. Biomass: Regenerable Energy; Wiley and Sons: Hoboken, NJ, USA, 1987; ISBN 0-471-90919-X.

46. Gradziuk, P.; Wojtaszek, Z. Alternatywne wykorzystanie gruntów rolniczych na cele niezwiązane z produkcją żywności. In Procesy Dostosowawcze Produkcji Roślinnej w Polsce w Kontekście Integracji z Unia Europejska; Klepacki, B., Ed.; SGGW: Warsaw, Poland, 2002; pp. 213-228. ISBN 83-88368-19-2.

47. Su, Y.; Zhang, P.; Su, Y. An overview of biofuels policies and industrialization in the major biofuel producing countries. Renew. Sustain. Energy Rev. 2015, 50, 991-1003. [CrossRef]

48. Finlay, M.R. Old efforts at new uses: A brief history of Chemurgy and the American search for biobased materials. J. Ind. Ecol. 2003, 7, 33-46. [CrossRef]

49. European Commission. Communication from the Commission. Energy for the Future: Renewable Sources of Energy. White Paper for a Community Strategy and Action Plan, COM(97)599 Final, Brussels. 1997. Available online: https://europa.eu/ documents/comm/white_papers/pdf/com97_599_en.pdf (accessed on 10 May 2021).

50. Buyx, A.; Tait, J. Biofuels: Ethics and policy-making. Biofuels Bioprod. Biorefin. 2011, 5, 631-639. [CrossRef]

51. Thompson, P.B. The agricultural ethics of biofuels: The food vs. fuel debate. Agriculture 2012, 2, 339-358. [CrossRef]

52. Gomiero, T.; Paoletti, M.; Pimentel, D. Biofuels: Efficiency, ethics, and limits to human appropriation of ecosystem services. J. Agric. Environ. Ethics 2009, 23, 403-434. [CrossRef]

53. Mohr, A.; Raman, S. Lessons from first generation biofuels and implications for the sustainability appraisal of second generation biofuels. Energy Policy 2013, 63, 114-122. [CrossRef]

54. Huang, J.; Yang, J.; Msangi, S.; Rozelle, S.; Weersink, A. Global biofuel production and poverty in China. Appl. Energy 2012, 98, 246-255. [CrossRef]

55. Timilsina, G.; Shrestha, A. An overview of global markets and policies. In The Impacts of Biofuels on the Economy, Environment and Poverty; Springer Science and Business Media LLC: Berlin/Heidelberg, Germany, 2014; pp. 1-14. [CrossRef]

56. Gomiero, T. Are biofuels an effective and viable energy strategy for industrialized societies? A reasoned overview of potentials and limits. Sustainability 2015, 7, 8491-8521. [CrossRef]

57. Mol, A.P. Environmental authorities and biofuel controversies. Environ. Polit. 2010, 19, 61-79. [CrossRef]

58. Selbmann, K.; Pforte, L. Evaluation of Ecological Criteria of Biofuel Certification in Germany. Sustainability 2016, 8, 936. [CrossRef]

59. Lane, J. Letter Sent to Dutch Cabinet by 178 Dutch Scientists Urges End to Food-Based Biofuels. Available online: http: / / www.biofuelsdigest.com/bdigest/2017/12/04/letter-sent-to-dutch-cabinet-by-178-dutch-scientists-urges-end-tofood-based-biofuels / (accessed on 23 November 2020).

60. Cao, Y.; Pawlowski, L. Effect of Biofuels on Environment and Sustainable Development. Ecol. Chem. Eng. 2013, 20, 799-804. [CrossRef]

61. Copa Cogeca. Phasing Out First Generation Biofuels: What Is at Stake? Available online: http://copa-cogeca.eu/Download. ashx?ID=1590445 (accessed on 22 November 2020). 
62. Falck-Zepeda, J.; Msangi, S.; Sulser, T.; Zambrano, P.; Falconi, C. Biofuels and Rural Economic Development in Latin America and the Caribbean; Cooperation Programme FAO/Inter-American Development Bank Latin America and the Caribbean Service Investment Centre Division: Washington, DC, USA, 2010. Available online: https://publications.iadb.org/publications/english/document/ Biofuels-and-Rural-EconomicDevelopment-in-Latin-America-and-the-Caribbean.pdf (accessed on 20 November 2020).

63. USDA Foreign Agricultural Service; Global Agricultural Information Network. EU Biofuels Annual 2017. GAIN Report No. NL7015. Available online: https:/ /apps.fas.usda.gov/newgainapi/api/report/downloadreportbyfilename?filename=Biofuels\% 20Annual_The\%20Hague_EU-28_6-19-2017.pdf (accessed on 24 November 2020).

64. Stattman, S.L.; Gupta, A.; Partzsch, L.; Oosterveer, P. Toward sustainable biofuels in the European Union? Lessons from a decade of hybrid biofuel governance. Sustainability 2018, 10, 4111. [CrossRef]

65. Directive (EU) 2015/1513 of the European Parliament and of the Council of 9 September 2015 Amending Directive 98/70/EC Relating to the Quality of Petrol and Diesel Fuels and Amending Directive 2009/28/EC on the Promotion of the Use of Energy from Renewable Sources. 2015. Available online: https://eur-lex.europa.eu/legal-content/EN/TXT/PDF/?uri=CELEX: 32015L1513\&from $=$ EN (accessed on 20 November 2020).

66. Directive (EU) 2018/2001 of the European Parliament and of the Council of 11 December 2018 on the Promotion of the Use of Energy from Renewable Sources (Recast). 2018. Available online: https:/ / eur-lex.europa.eu/legal-content/EN/TXT/PDF/?uri= CELEX:32018L2001\&from=EN (accessed on 21 November 2020).

67. Gradziuk, P.; Grzybek, A.; Kowalczyk, K.; Kościk, B. Biopaliwa; Wydawnictwo Wieś Jutra: Warsaw, Poland, 2002; ISBN 83-7160-217-0.

68. Guo, M.; Song, W.; Buhain, J. Bioenergy and biofuels: History, status, and perspective. Renew. Sustain. Energy Rev. 2015, 42, 712-725. [CrossRef]

69. Giampietro, M.; Ulgiati, S.; Pimentel, D. Feasibility of large-scale biofuel production-Does an enlargement of scale change the picture? BioScience 1997, 47, 587-600. [CrossRef]

70. Demirbas, A. Biofuels sources, biofuel policy, biofuel economy and global biofuel projections. Energy Convers. Manag. 2008, 49, 2106-2116. [CrossRef]

71. International Energy Agency (IEA). Technology Roadmap: Biofuels for Transport. Available online: https://webstore.iea.org/ download/direct/ 632 (accessed on 27 November 2020).

72. United Nations Conference on Trade and Development. Biofuel Production Technologies: Status, Prospects and Implications for Trade and Development. Available online: https:/ / unctad.org/system/files/official-document/ditcted200710_en.pdf (accessed on 21 November 2020).

73. Stafford, W.; Lotter, A.; Brent, A.; von Maltitz, G. WIDER Working Paper 2017/87. The United Nations University World Institute for Development Economics Research. Biofuels Technology. Available online: https://www.wider.unu.edu/sites/default/files/ wp2017-87.pdf (accessed on 21 November 2020).

74. UFOP Union zur Förderung von Oel- und Proteinpflanzen E.V. UFOP Report on Global Market Supply 2018/2019. Available online: https:/ / www.ufop.de/files/4815/4695/8891/WEB_UFOP_Report_on_Global_Market_Supply_18-19.pdf (accessed on 27 November 2020).

75. Aron, N.S.M.; Khoo, K.S.; Chew, K.W.; Show, P.L.; Chen, W.-H.; Nguyen, T.H.P. Sustainability of the four generations of biofuels-A review. Int. J. Energy Res. 2020, 44, 1-17. [CrossRef]

76. International Renewable Energy Agency (IRENA). Advanced Biofuels. What Holds Them Back? Available online: https: //www.irena.org/-/media/Files/IRENA/Agency/Publication/2019/Nov/IRENA_Advanced-biofuels_2019.pdf (accessed on 21 November 2020).

77. Oh, Y.-K.; Hwang, K.-R.; Kim, C.; Kim, J.R.; Lee, J.-S. Recent developments and key barriers to advanced biofuels: A short review. Bioresour. Technol. 2018, 257, 320-333. [CrossRef]

78. IEA Bioenergy; Brown, A.; Waldheim, L.; Landälv, I.; Saddler, J.; Ebadian, M.; McMillan, J.D.; Bonomi, A.; Klein, B. Advanced Biofuels-Potential for Cost Reduction. Available online: http://task39.sites.olt.ubc.ca/files/2020/02/Advanced-BiofuelsPotential-for-Cost-Reduction-Final-Draft.pdf (accessed on 26 November 2020).

79. Commission of the European Communities. Proposal for a Council Regulation (EEC) on the Implementation in the SolarEnergy Sector of Council Regulation (EEC) No 1302/78 of 12 June 1978 on the Granting of Financial Support for Projects to Exploit Alternative Energy Sources. Available online: http:/ / aei.pitt.edu/32677/1/COM_(78)_511_final_1.pdf (accessed on 26 November 2020).

80. Council Resolution of 9 June 1980 Concerning Community Energy Policy Objectives for 1990 and Convergence of the Policies of the Member States. Available online: https:/ / eur-lex.europa.eu/legal-content/EN/TXT/PDF/?uri=CELEX:31980Y0618(01)\& from=EN (accessed on 4 June 2021).

81. Opinion on a Community Orientation to Develop New and Renewable Energy Sources (') (86/C 207/05). Available online: https:/ / eur-lex.europa.eu/legal-content/EN/TXT/PDF/?uri=CELEX:51986AC0504\&from=EN (accessed on 26 November 2020).

82. Council Resolution of 16 September 1986 Concerning New Community Energy Policy Objectives for 1995 and Convergence of the Policies of the Member States. Available online: https:/ / eur-lex.europa.eu/legal-content/EN/TXT/PDF/?uri=CELEX: 31986Y0925(01)\&qid=1606834484404\&from=EN (accessed on 26 November 2020). 
83. Commission of the European Communities. Communication from the Commission. Energy for the Future: Renewable Sources of Energy. Green Paper for a Community Strategy and Action Plan. Available online: http://aei.pitt.edu/1280/1/renewalbe_ energy_gp_COM_96_576.pdf (accessed on 29 November 2020).

84. Solorio, I.; Jörgens, H. (Eds.) A Guide to EU Renewable Energy Policy: Comparing Europeanization and Domestic Policy Change; Edvard Elgar: Cheltenham, UK, 2017; ISBN 9781783471553.

85. Directive 2003/30/EC of the European Parliament and of the Council of 8 May 2003 on the Promotion of the Use of Biofuels or Other Renewable Fuels for Transport. Available online: https:/ / eur-lex.europa.eu/legal-content/EN/TXT/PDF/?uri=CELEX: 32003L0030\&from $=$ en (accessed on 29 November 2020).

86. Communication from the Commission-Biomass Action Plan \{SEC(2005) 1573\}. Available online: https:/ / eur-lex.europa.eu/legalcontent/EN/TXT/PDF/?uri=CELEX:52005DC0628\&from=EN (accessed on 29 November 2020).

87. Commission of the European Communities. Communication from the Commission An EU Strategy for Biofuels \{SEC(2006) aaaa\}. Available online: http://www.cres.gr/biodiesel/downloads/EU\%20Strategy\%20for\%20biofuels.pdf (accessed on 29 November 2020).

88. Commission of the European Communities. Communication from the Commission to the Council and the European Parliament. Renewable Energy Road Map Renewable Energies in the 21st Century: Building a More Sustainable Future. Available online: https: / / eur-lex.europa.eu/LexUriServ /LexUriServ.do?uri=COM:2006:0848:FIN:EN:PDF (accessed on 29 November 2020).

89. Directive 2009/28/EC of the European Parliament and of the Council of 23 April 2009 on the Promotion of the Use of Energy from Renewable Sources and Amending and Subsequently Repealing Directives 2001/77/EC and 2003/30/EC (Text with EEA Relevance). Available online: https:/ / eur-lex.europa.eu/legal-content/EN/TXT/PDF/?uri=CELEX:32009L0028\&from=EN (accessed on 29 November 2020).

90. Directive 2009/30/EC of the European Parliament and of the Council of 23 April 2009 Amending Directive 98/70/EC as Regards the Specification of Petrol, Diesel and Gas-Oil and Introducing a Mechanism to Monitor and Reduce Greenhouse Gas Emissions and Amending Council Directive 1999/32/EC as Regards the Specification of Fuel Used by Inland Waterway Vessels and Repealing Directive 93/12/EEC (Text with EEA Relevance). Available online: https:/ / eur-lex.europa.eu/legal-content/EN/ TXT/PDF/?uri=CELEX:32009L0030\&from=EN (accessed on 29 November 2020).

91. Lonza, L.; Deix, S.; Maas, H.; Caiado, C.; Hamje, H.D.C.; Reid, A. EU Renewable Energy Targets in 2020: 2015 Legislative Update; Publications Office of the European Union: Luxembourg, 2016. [CrossRef]

92. Ministry of Agriculture and Rural Development of Poland; Ministry of Environment of Poland. Kodeks Dobrej Praktyki Rolniczej; Foundation of Agricultural Assistance Programs: Warsaw, Poland, 2004; p. 98. Available online: http://iung.pl/dpr_eng/ publikacje/kodeks_dobrej_praktyki_rolniczej.pdf (accessed on 30 November 2020).

93. USDA Foreign Agricultural Service; Global Agricultural Information Network. EU Biofuels Annual 2020. GAIN Report No. E42020-0032. Available online: https://apps.fas.usda.gov/newgainapi/api/Report/DownloadReportByFileName?fileName= Biofuels\%20Annual_The\%20Hague_European\%20Union_06-29-2020 (accessed on 30 November 2020).

94. International Energy Agency. Renewables 2019 Analysis and Forecast to 2024. Available online: https://webstore.iea.org/ download/direct/2854?fileName=Renewables_2019.pdf (accessed on 30 November 2020).

95. Official Journal of the European Communities. Court of Auditors Special Report 6/2002. Available online: https://eur-lex. europa.eu/LexUriServ / LexUriServ.do?uri=OJ:C:2002:254:0001:0022:EN:PDF (accessed on 30 November 2020).

96. Schoepe, M. Economic Effects of the Production of Biodiesel for Use as Fuel. Ifo Institute for Economic Research at the University Munich, Final Report Ifo Schnelldienst. Manuscript 59(17). 2006, pp. 1-10. Available online: http://www. globalbioenergy.org/uploads/media/0611_IFO_-_Economic_effects_of_the_production_of_biodiesel_for_use_as_fuel.pdf (accessed on 30 November 2020).

97. Jabłoński, K.; Skarżyńska, A.; Abramczuk, Ł. Determinants of income from wheat and rape production in projection for 2020 in Poland. Žemés Ūkio Moksl. 2015, 22, 229-239. [CrossRef]

98. Blanco Fonseca, M.; Burrell, A.; Gay, S.H.; Henseler, M.; Kavallari, A.; M’Barek, R.; Pérez Domínguez, I.; Tonini, A. Impacts of the EU Biofuel Target on Agricultural Markets and Land Use: A Comparative Modelling Assessment; European Commission, Joint Research Centre, Institute for Prospective Technological Studies: Luxembourg, 2010; ISBN 978-92-79-16310-4. [CrossRef]

99. Mazzilli, S.R.; Ernst, O.R. Rapeseed-to-wheat yield ratio in different production environments and effects on subsequent summer crops yields. Agrosyst. Geosci. Environ. 2019, 2, 190017. [CrossRef]

100. Petersen, J.; Haastrup, M.; Knudsen, L.; Olesen, J.E. Causes of Yield Stagnation in Winter Wheat in Denmark. DJF Report PLANT SCIENCE NO. 147; Faculty of Agricultural Sciences Aarhus University: Tjele, Denmark, 2010; ISBN 87-91949-46-7. Available online: https: / dcapub.au.dk/djfpublikation/djfpdf/DJF-Rap.Mark147-internet.pdf (accessed on 29 November 2020).

101. Sieling, K.; Christen, O. Crop rotation effects on yield of oilseed rape, wheat and barley and residual effects on the subsequent wheat. Arch. Agron. Soil Sci. 2015, 61, 1531-1549. [CrossRef]

102. Kuś, J. Znaczenie płodozmianu we współczesnym rolnictwie. Studia Rap. IUNG-PIB 2015, 43, 65-87. [CrossRef]

103. Angus, J.F.; Kirkegaard, J.A.; Hunt, J.R.; Ryan, M.H.; Ohlander, L.; Peoples, M.B. Break crops and rotations for wheat. Crop Pasture Sci. 2015, 66, 523-552. [CrossRef]

104. Darguza, M.; Gaile, Z. Yield and quality of winter wheat, depending on crop rotation and soil tillage. Res. Rural. Dev. 2019, 2, 29-35. [CrossRef]

105. Kovács, A. The role of beekeeping in production of oil crops. Appl. Stud. Agribus. Commer. 2013, 7, 77-82. [CrossRef] 
106. Perrot, T.; Gaba, S.; Roncoroni, M.; Gautier, J.-L.; Bretagnolle, V. Bees increase oilseed rape yield under real field conditions. Agric. Ecosyst. Environ. 2018, 266, 39-48. [CrossRef]

107. Ramos, M.; Soares Dias, A.P.; Puna, J.F.; Gomes, J.; Bordado, J.C. Biodiesel Production Processes and Sustainable Raw Materials. Energies 2019, 12, 4408. [CrossRef]

108. Gradziuk, P.; Gradziuk, B. Employment impacts of renewable energy in UE. Proceedings of the International Scientific Conference. Econ. Sci. Agribus. Rural Econ. 2018, 1, 259-267. [CrossRef]

109. Donfouet, H.P.P.; Barczak, A.; Détang-Dessendre, C.; Maigné, E. Crop production and crop diversity in France: A Spatial analysis. Ecol. Econ. 2017, 134, 29-39. [CrossRef]

110. Schils, R.; Olesen, J.E.; Kersebaum, K.-C.; Rijka, B.; Oberforsterd, M.; Kalyadae, V.; Khitrykaue, M.; Gobinf, A.; Kirchevg, H.; Manolovag, V.; et al. Cereal yield gaps across Europe. Eur. J. Agron. 2018, 101, 109-120. [CrossRef]

111. Nowak, A. Differentiation in cereal production among Member States of the European Union. Pol. J. Agron. 2020, 40, 7-15. [CrossRef]

112. Stuczyński, T.; Łopatka, A.; Faber, A.; Czaban, P.; Kowalik, M.; Koza, P.; Korzeniowska-Pucułek, R.; Siebielec, G. Prognoza wykorzystania przestrzeni rolniczej dla produkcji roślin na cele energetyczne. Studia Rap. IUNG-PIB 2008, 11, 25-42. [CrossRef]

113. Rachoń, L.; Kawczyńska, M. Changes in the structure of sowing area, yields and harvests of cereal crops in Poland in the years 1965-2015. Agron. Sci. 2018, 73, 5-13. [CrossRef]

114. Jarosz, Z.; Faber, A.; Syp, A. Influence of raw materials used for biofuels production on the structure sown. Rocz. Nauk. Stow. Ekon. Rol. Agrobiz. 2013, 15, 4.

115. Augustyńska, I. Opłacalność Produkcji Wybranych Produktów Rolniczych w Polsce w Latach 2013-2017. Instytut Ekonomiki Rolnictwa i Gospodarki Żywnościowej-Państwowy Instytut Badawczy w Warszawie. 2018. Available online: http:/ /agro.icm. edu.pl/agro/element/bwmeta1.element.agro-b3d3b197-950c-4a08-9f8f-b3e727b25c18/c/152.pdf (accessed on 18 October 2021).

116. Skarżyńska, A.; Augustyńska, I.; Czułowska, M.; Abramczuk, Ł. Produkcja, Koszty i Dochody z Wybranych Produktów Rolniczych w Latach 2018-2019; Instytut Ekonomiki Rolnictwa i Gospodarki Żywnościowej-Państwowy Instytut Badawczy w Warszawie: Warszawa, Poland, 2020; ISBN 978-83-7658-840-7.

117. Jończyk, K. Oddziaływanie Siedmiu Czynników Agrotechnicznych na Plonowanie Pszenicy Ozimej w Doświadczeniach z Replikacja Połówkowa; Seria R; Instytut Uprawy, Nawożenia i Gleboznastwa w Puławach: Puławy, Poland, 1997; p. 346.

118. Rondanini, D.P.; Gomez, N.V.; Agosti, M.B.; Miralles, D.J. Global trends of rapeseed grain yield stability and rapeseed-to-wheat yield ratio in the last four decades. Eur. J. Agron. 2012, 37, 56-65. [CrossRef]

119. Budzyński, W.; Ojczyk, T. Rzepak-Produkcja Surowca Olejarskiego; Wyd. ART: Olsztyn, Poland, 1996.

120. Oleszek, W.; Ascard, J.; Johansson, H. Brassicae jako rośliny alternatywne umożliwiające kontrole zachwaszczenia w rolnictwie zachowawczym. Fragm. Agron. 1994, 11, 5-19.

121. Kuś, J.; Jończyk, K.; Kawalec, A. Czynniki ograniczające plonowanie pszenicy ozimej w różnych systemach gospodarowania. Acta Agrophys. 2007, 10, 407-417.

122. Kuś, J.; Jończyk, K. Produkcyjne i środowiskowe Skutki Stosowania różnych Systemów Gospodarowania w Osinach. In Eksperymenty Wieloletnie w Badaniach Rolniczych w Polsce; Marks, M., Ed.; Wydawnictwo Uniwersytetu Warmińsko-Mazurskiego: Olsztyn, Poland, 2018; pp. 133-156. ISBN 978-83-8100-132-8.

123. Lautenbach, S.; Seppelt, R.; Liebscher, J.; Dormann, C. 2012: Spatial and temporal trends of global pollination benefit. PLoS ONE 2012, 7, e35954. [CrossRef] [PubMed]

124. Potts, S.G.; Imperatriz-Fonseca, V.; Ngo, H.T.; Aizen, M.A.; Biesmeijer, J.C.; Breeze, T.D.; Dicks, L.V.; Garibaldi, L.A.; Hill, R.; Settele, J.; et al. Safeguarding pollinators and their values to human well-being. Nature 2016, 540, 220-229. [CrossRef] [PubMed]

125. Porto, R.G.; de Almeida, R.F.; Cruz-Neto, O.; Tabarelli, M.; Viana, B.F.; Peres, C.A.; Lopes, A.V. Pollination ecosystem services: A comprehensive review of economic values, research funding and policy actions. Food Sec. 2020, 12, 1425-1442. [CrossRef]

126. Majewski, J. Determinanty opłacalności produkcji pszczelarskiej w Polsce. Rocz. Nauk. Stowarzyszenia Ekon. Rol. Agrobiz. 2018, 20, 105-111. [CrossRef]

127. Kołtowski, Z. Beekeeping value and pollination requirements of double-improved cultivars of spring rapeseed (Brassica napus L. var. oleifera Metzger f. annua Thell.). J. Apic. Sci. 2001, 45, 69-84.

128. Kołtowski, Z. Beekeeping value of recently cultivated winter rapeseed cultivars. J. Apic. Sci. 2002, 46, $23-34$.

129. Lipiński, M. Pożytki Pszczele, Zapylanie i Miododajność Roślin; Kołtowski, Z., Ed.; PWRiL, Wydawnictwo Sądecki Bartnik-Stroże: Warszawa, Poland, 2010; p. 320. ISBN 978-83-09-99024-6.

130. Kołtowski, Z. The effect of pollinating insects on the yield of winter rapeseed (Brassica napus L. var. napus f. biennis) cultivars. J. Apic. Sci. 2005, 49, 29-41. 